\title{
Publisher Correction: Medusozoan genomes inform the evolution of the jellyfish body plan
}

Konstantin Khalturin (D), Chuya Shinzato, Maria Khalturina, Mayuko Hamada, Manabu Fujie, Ryo Koyanagi D, Miyuki Kanda, Hiroki Goto, Friederike Anton-Erxleben, Masaya Toyokawa, Sho Toshino and Noriyuki Satoh D

Correction to: Nature Ecology \& Evolution https://doi.org/10.1038/s41559-019-0853-y, published online 15 April 2019.

The version of this article originally published was not open access, but should have been open access. The error has been corrected, and the paper is now open access with a CC-BY license.

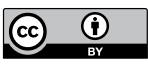

Open Access This article is licensed under a Creative Commons Attribution 4.0 International License, which permits use, sharing, adaptation, distribution and reproduction in any medium or format, as long as you give appropriate credit to the original author(s) and the source, provide a link to the Creative Commons license, and indicate if changes were made. The images or other third party material in this article are included in the article's Creative Commons license, unless indicated otherwise in a credit line to the material. If material is not included in the article's Creative Commons license and your intended use is not permitted by statutory regulation or exceeds the permitted use, you will need to obtain permission directly from the copyright holder. To view a copy of this license, visit http://creativecommons.org/licenses/ by/4.0/.

Published online: 2 May 2019

https://doi.org/10.1038/s41559-019-0905-3 